\title{
DOES SUDDEN UNEXPECTED DEATH IN CHILDREN WITH EPILEPSY OCCUR MORE FREQUENTLY IN THOSE WITH HIGH SEIZURE FREQUENCY?
}

\author{
Vera C. Terra', Fulvio A. Scorza', Américo C. Sakamoto', Kylvia G.F.D. Pinto', \\ Regina M.F. Fernandes', Ricardo M. Arida', Esper A. Cavalheiro', Hélio R. Machado'
}

\begin{abstract}
People with epilepsy are more likely to die prematurely and the most common epilepsy-related category of death is sudden unexpected death in epilepsy (SUDEP). Several studies have reported a moderate or high seizure frequency among SUDEP cases and SUDEP is considered rare in patients in remission. Method: We reviewed the occurrence of SUDEP in our epilepsy unit over an 8-year period to identify a potential association between seizure frequency and SUDEP occurrence in children with epilepsy. Results: From 835 patients evaluated, 12 had suffered SUDEP and nearly all of the SUDEP cases in our children are related to chronic uncontrolled epilepsy (daily $-50.0 \%$, two to four/week $-41.7 \%$, monthly $-8.3 \%$ ). Conclusion: SUDEP is not a rare event in children and increased mortality was recorded in those individuals who had not responded to pharmacologic treatment. Improved seizure control seems to be one of the most important measures to prevent SUDEP.
\end{abstract}

KEY WORDS: epilepsy, children, sudden death, seizure frequency.

\begin{abstract}
Morte súbita em crianças com epilepsia ocorre naquelas que apresentam maior frequência de crises?
Resumo - Pessoas com epilepsia têm maior chance de morrer prematuramente e a principal causa de morte relacionada à epilepsia é a morte súbita em epilepsia (SUDEP). Vários estudos têm relatado uma freqüência de crises moderada ou elevada em pacientes com SUDEP e SUDEP é considerada rara em pacientes em remissão. Método: Revisamos a ocorrência de SUDEP em nossa unidade de epilepsia por um período de oito anos com o objetivo de identificar uma possivel associação entre freqüência de crises e a ocorrência de SUDEP em crianças com epilepsia. Resultados: De 835 pacientes avaliados, 12 evoluíram com SUDEP e a maioria das crianças apresentava epilepsia crônica não controlada (50\% com crises diárias; $41,7 \%$ com duas a quatro crises/ semana; $8,3 \%$ com crises mensais). Conclusão: SUDEP não é um evento raro em crianças e maior mortalidade foi observada em indivíduos que não responderam ao tratamento medicamentoso. Melhor controle de crises parece ser uma das principais medidas na prevenção de SUDEP.
\end{abstract}

PALAVRAS-CHAVE: epilepsia, crianças, morte súbita, frequência de crises.

People with epilepsy are more likely to die prematurely than those without epilepsy and the most common epilepsy-related category of death is sudden unexpected death in epilepsy (SUDEP) . $^{1,2}$ A number of associated factors for SUDEP have been reported but the results are not wholly consistent between studies. These include presence of generalized tonic-clonic seizures, polytherapy with antiepileptic drugs, young age, duration of the seizure disorder ranging from 15 to 20 years, early onset of epilepsy and more-frequent seizures ${ }^{1,2}$.

In line with the latter risk factors, the impact of high seizure frequency on the risk of SUDEP has been evaluated from different angles: most studies including information on seizure control have reported a moderate or high sei-

'Departamento de Neurociências e Ciências do Comportamento. Faculdade de Medicina de Ribeirão Preto, Universidade de São Paulo, Ribeirão Preto SP, Brasil; ${ }^{2}$ Disciplina de Neurologia Experimental, Universidade Federal de São Paulo/Escola Paulista de Medicina (UNIFESP/EPM), São Paulo SP, Brasil; ${ }^{3}$ Departamento de Fisiologia, Universidade Federal de São Paulo/Escola Paulista de Medicina (UNIFESP/EPM), São Paulo SP, Brasil.

The authors thank FAPESP, CInAPCe-FAPESP and CNPq for supporting this study.

Received 23 June 2009, received in final form 3 August 2009. Accepted 30 September 2009.

Dr. Fulvio Alexandre Scorza - Disciplina de Neurologia Experimental - Rua Botucatu 862 -04023-900 São Paulo SP-Brasil. E-mail: scorza.nexp@epm.br 
Table. Seizure frequency in patients with SUDEP.

\begin{tabular}{ccccc}
\hline N & Sex & Age epilepsy onset (years) & Age at death (years) & Seizure frequency \\
\hline 1 & F & 1 & 11 & Three / week \\
2 & F & 2 & 8 & Daily \\
3 & F & 0.8 & 3 & Two / year \\
4 & F & 0 & 2 & Four / year \\
5 & M & 0.6 & 2 & Daily \\
6 & F & 8 & 11 & One / month \\
7 & M & 0.7 & 9 & Daily \\
8 & M & 0.6 & 11 & Daily \\
9 & F & 1.6 & 3 & Daily \\
10 & M & 0.5 & 9 & Two / week \\
11 & M & 2 & 16 & Daily \\
12 & M & 4 & 17 & Three / week \\
\hline
\end{tabular}

M: male; F: female.

zure frequency among SUDEP cases ${ }^{2}$ and SUDEP is considered rare in patients in remission and only few such cases have been reported ${ }^{2}$.

As SUDEP is mainly, but exclusively, a problem for patients with uncontrolled epilepsy ${ }^{1,2}$, the aim of this study was verify a possible association between seizure frequency and sudden unexpected death of children with epilepsy.

\section{METHOD}

We reviewed the occurrence of SUDEP in our epilepsy unit over an 8-year period to identify a potential association between seizure frequency and SUDEP occurrence in children with epilepsy. Our study evaluated the incidence of SUDEP in a cohort of children aged between zero and 18 years, evaluated in the Clinical Hospital of Ribeirão Preto in 2000 and followed up until June 2008. The Ribeirão Preto epilepsy center is a tertiary referral center in Brazil that provides services for pediatric patients from all over the country. A retrospective medical history of 996 patients was reviewed to investigate the occurrence of SUDEP. From 996 patients evaluated, 11 had suffered SUDEP. All the cases with dubious diagnosis of epilepsy were excluded from the study. Patients with exclusive febrile seizures or a single seizure were not considered in this study. The criteria for SUDEP were as follows: (1) Child with epilepsy and recurrent unprovoked seizures; (2) The child died unexpectedly while in a reasonable state of health; (3) Death occurred suddenly; (4) Death occurred during normal activities in benign circumstances; (5) An obvious medical cause of death was not found; (6) The death was not directly caused by status epilepticus. We considered that SUDEP was probable when all the above-mentioned criteria were present, but post-mortem data were not available. SUDEP was considered possible when conclusive and post-mortem data were lacking.

\section{RESULTS}

Detailed results are described in Table. In brief, our study demonstrated that SUDEP in children with epilepsy is not a rare event and nearly all of the SUDEP cases in our children are related to chronic uncontrolled epilepsy (daily $-50.0 \%$, two to four/week $-41.7 \%$, monthly $-8.3 \%$ ).

\section{DISCUSSION}

The possibility of SUDEP is very frightening for parents of a child with epilepsy. ${ }^{3}$. As we know, SUDEP is a significant cause of mortality in adults with epilepsy, however; only a few data exist about this risk in children ${ }^{3}$. The study developed here is totally in agreement with previous results evaluated in adults with epilepsy, where increased mortality was recorded in those individuals who had not responded to treatment, with no increase in risk observed in patients who remained seizure free ${ }^{4,5}$. Where do you go from here? Improved seizure control by treatment (pharmacological or surgical) seems to be one of the most important measures to prevent SUDEP. In the mean time, other actions than medical and surgical therapies may help to prevent SUDEP, such as altered sleeping arrangements, seizure alarms, omega- 3 supplementation and physical activity ${ }^{1,5,6}$.

\section{REFERENCES}

1. Tomson T, Nashef L, Ryvlin P. Sudden unexpected death in epilepsy: current knowledge and future directions. Lancet Neurol 2008;7: 1021-1031.

2. Tomson T, Walczak T, Sillanpaa M, et al. Sudden unexpected death in epilepsy: a review of incidence and risk factors. Epilepsia 2005;46:54-61.

3. Camfield P, Camfield C. Sudden unexpected death in people with epilepsy: a pediatric perspective. Semin Pediatr Neurol 2005;12:10-14.

4. Mohanraj R, Norrie J, Stephen LJ, et al. Mortality in adults with newly diagnosed and chronic epilepsy: a retrospective comparative study. Lancet Neurol 2006;5:481-487.

5. Brodie MJ, Holmes GL. Should all patients be told about sudden unexpected death in epilepsy (SUDEP)? Pros and Cons. Epilepsia 2008;49: 99-101.

6. Scorza FA, Colugnati DB, Pansani AP, et al. Preventing tomorrow's sudden cardiac death in epilepsy today: what should physicians know about this? Clinics 2008;63:389-394 